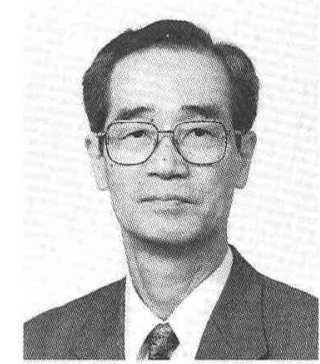

曾我 直弘
ガラスの最大の強みは透明で着色できること とリサイクルが可能なことであり、最大の弱み は壊れやすいことである。昨年、日本学術会議 がホストとなって開催した世界科学アカデミー 会議（IAP2000）に扎いて、薄青色のリサイク ルガラスマグが記念品として配られたが、これ は前者の特徴を活かしたものであり、そこに書 かれていた F. S. Roland IAP共同委員長の銘文 “Earth is fragile” は地球を後者の特性になぞら えたものといえる。

20 世紀にはこのようなガラス固有の特性を最 大限利用した製品を開発し、弱点を改善するこ とを目指して研究開発が行われ、またオイルシ ヨック以後には省エネルギー対策や排ガス規制 対策に取り組んできたが、21世紀ではさらに縓 しくなる品質やエネルギー・環境問題に対応す るために新しい技術が必要となっている。

この「新世紀におけるガラス：挑戦とブレー クスルー技術」を主題に、国際ガラス委員会年 次大会が平成12年5月15日から17日までアムス テルダムで開催され、同時に理事会も開かれた ので出席した。

\section{国際的工学団体と 国際ガラス委員会}

国際ガラス委員会 (International Commission on Glass, ICG) は国際工学団体連合 (The International Union of Technical Associations and Organizations: UATI）に所属している。

UATIは、UNESCOが技術や工業分野と緊密 な関係を保つために主導して1951年に設立され たもので、そこに属する280国際団体は、それ ぞれの分野における科学技術の振興を目指して 産業界と連携して活動している。世界的な工学 系NGOとしては、UATIに加えて日本学術会議 が加入している世界工学団体連盟 (World Federation of Engineering Organizations: WFEO) が同様にUNESCOによって1968年に設立され ているが、1994年にUNESCOのパートナーで ある両団体はICET (International Council for Engineering and Technology)を構成している。 ICGそのものは、20世紀初頭に国を超えて製 品や技術の交流が盛んとなり学術・技術用語の 比較、製品の特性値の規格化、あるいは情報の 交換が必要となったために、1933年にヨーロッ パのガラス科学者と技術者が中心となって設立 
され、ベニスにおいて第1回国際ガラス会議 (International Congress on Glass) を開催して 以降、第2次大戦中を除いて 3 年ごとに大会を、 その間に年会を 27 の加盟国がホストとなって開 催している。我が国からは日本学術会議の登録 学術研究団体である日本セラミックス協会が 1936年から日本の代表団体となって参加してお り、2004年には1974年以来30年ぶりに京都で大 会を開くことが前回の理事会で決定され、それ に向けて国内で準備が進められている。

\section{新世紀に向けた ガラスの研究開発の動向}

今回のホスト国となったオランダでは、オラ ンダ応用科学研究機構TNOの応用物理研究所 材料部門がガラス工業会と連携してガラス溶融 技術、製品開発に取り組み、世界をリードする 多くの成果をあげている。年会にはヨーロッパ を中心に産業界の研究所からの多くの参加者が あった。学術関係では64件の発表があり、ガラ スの仮想温度や緩和現象、イオン拡散・融体挙 動などの動的挙動、核生成・結晶化などの熱力 学的特性、ガラス構造解明のためのキャラクタ リゼーション、新しいガラスの機械的・光学的 性質など次世代に重要となるガラスの特性が取 り扱われた。技術関係は 48 件で、ガラス製造の モデル化、環境対応を念頭に置いた溶融技術、 リサイクルを含むガラスの後処理などの取り組
みが発表された。

ヨーロッパ諸国に比べて、我が国におけるガ ラスの研究開発の歴史は浅い。装飾品としては ともかく、空ガラスや容器などの実用品として 我が国でガラスが普及するのは 20 世紀後半以降 である。しかし、第2次世界大戦後に欧米から 導入した基本技術に改善・改良を加えた結果、 我が国のガラス製造技術は現在世界のトップレ ベルにある。また、この時期からガラスも材料 科学研究の対象となり、構造や物性に関する研 究が進んだ結果、学術論文数においては欧米と 競うまでになっている。

残念ながら我が国の産と学の閉鎖性のために 両者の交流は少なく、互いの持つポテンシャル が十分に生かされていない。この状況は、国立 研究所や大学の独立行政法人化という組織变更 と、平成12年に策定された国家産業技術戦略に 則ったガラス産業技術戦略の実施によって改善 され、我が国から21世紀の諸問題を解決する新 しいガラスの科学技術が生まれることを期待し ている。

\section{社会の変化と国際組織の在り方}

理事会では、次世代におけるICGの活動の在 り方を検討してきた戦略策定委員会から報告書 が提出された。国内、国際を問わずNGO組織 が生き残るには、設立当時の目的や達成手段を 社会に動きに合わせて変えることが必要であ 
る。ICGでも最近の活動は各国から推薦された 産官学の 350 名余りの委員が共通する学術・技 術課題に取り組む委員会活動が中心である。

この報告では、ICGがさらに発展をするには ガラスを材料として使うすべての者が参画して いる組織とする必要があり、そのためには、例 えばIT関連などの新規なガラスへの取り組みを 重視すること、ヨーロッパに偏りがちな活動を 他の地域に広げる努力をすること、技術委員会 の成果をわかりやすい形で公開し、存在意義を 訴えること、技術移転に久かせない基礎的な技 術や科学の理解を助けるような教育活動を発展 途上国において行うことなどが指摘された。

さらに、旧社会主義国家の崩壊や経済不況に
よりもたらされる会費滞納を乗り切るための財 政基盤の強化や、若手を活動の中心に引き入れ る方策なども取り上げられたが、これらの多く は国内の学協会の体質改善のためにも考慮す心゙ き指摘であると思われる。

次は3年ごとに開催される国際ガラス会議が 2001年7月2～6日にスコットランドのエディン バラで開かれることになって打り、そこではガ ラスの科学・技術とともにガラス工芸・デザイ ン・歴史なども取り上げられる予定である。

兽我 直弘（そが なおひろ 1934年生）

日本学術会議第5部会員、材料工学研究連絡委員会委員、 滋賀県立大学工学部教授、京都大学名誉教授 専門：無機材料化学、無機工業化学

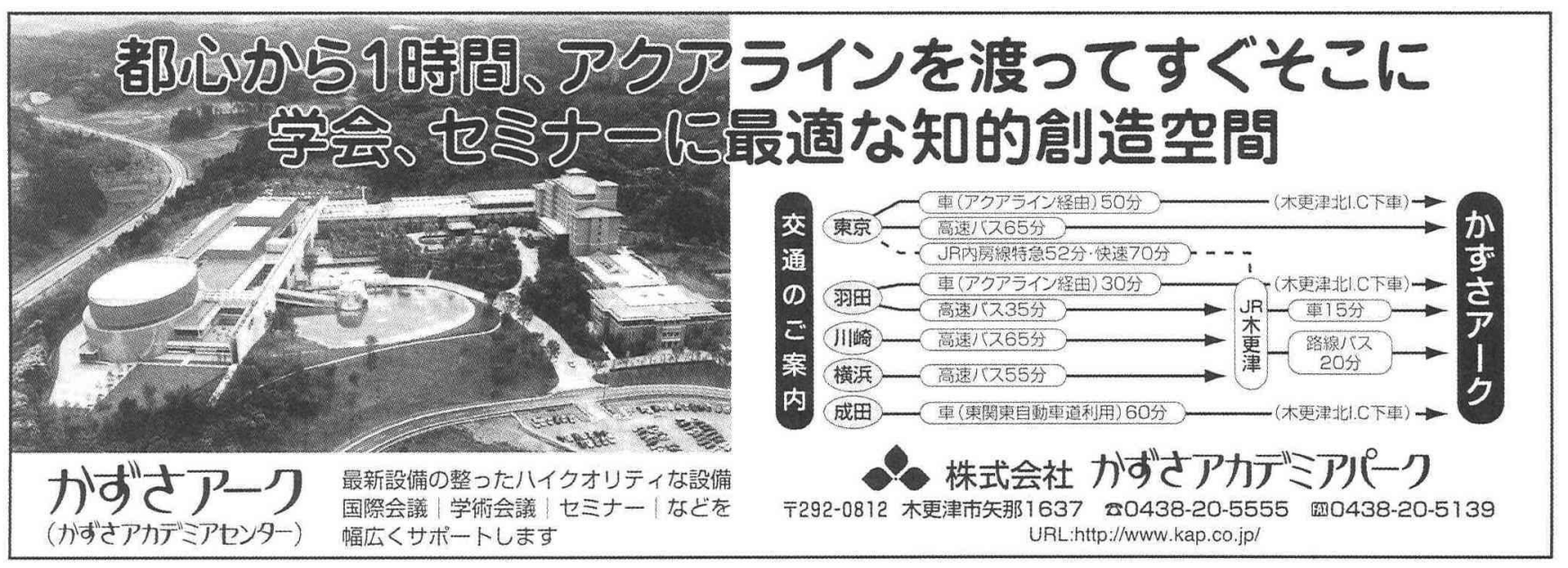

